\title{
STRATEGI DAKWAH MULTIMEDIA NAHDLATUL ULAMA MELALUI INSTAGRAM @NUONLINE_ID
}

\author{
Lutfi Fatmasari ${ }^{1)}$, Ahmad Nurcholis ${ }^{2)}$ Bobby Rachman Santoso ${ }^{3)}$ \\ Institut Agama Islam Negeri Tulungagung \\ e-mail: lutfifatma07@gmail.com ${ }^{1)}$, cholisahmad87@ gmail.com $^{2)}$ \\ bobby.indunisy@gmail.com ${ }^{3)}$
}

\begin{abstract}
ABSTRAK
Media dakwah seiring dengan berjalannya waktu terus mengalami perkembangan yang begitu baik. Munculnya media sosial ditengah masyarakat turut mempengaruhi kegiatan penyampaian pesan-pesan dakwah. Penelitian ini dilatarbelakangi oleh kontinuitas Nahdlatul Ulama sebagai organisasi dakwah terbesar di Indonesia dalam menerapkan strategi dakwah melalui akun instagram. Penelitian ini dilakukan pada akun instagram resmi Nahdlatul Ulama yaitu @nuonline_id. Penelitian ini bertujuan untuk memahami bagaimana format pesan dakwah yang disajikan akun@nuonline_id dan bagaimana strategi dakwah yang digunakan Nahdlatul Ulama pada akun @nuonline_id.Penelitian deskriptif kualitatif dipilih untuk menjadi metode penelitian dalam penelitian ini. Untuk mempermudah peneliti dalam memecahkan permasalahan maka, pendekatan yang digunakan adalah pendekatan content analysis. Dalam penelitian ini, hasilnya memperlihatkan bahwa @nuonline_id dari sisi bentuk konten mempunyai 2 strategi yaitu: pertama, dalam penyajian gambar yang diberi sisipan kata dan pemilihan template yang menunjukkan ciri khas Nahdlatul Ulama. Kedua, penyajian video dengan memberikan ilustrasi-ilustrasi menarik. Selain itu dari sisi sifat pesan, strategi juga dapat dilihat pada kandungan dalam pesan dakwah yang bersifat informatif, persuasif dan edukatif.
\end{abstract}

Kata Kunci: Strategi,Dakwah Multimedia,Instagram, @nuonline_id 


\begin{abstract}
Da'wah media over time continues to experience such good development. The emergence of social media in the community has also influenced the delivery of da'wah messages. This research is motivated by the continuity of Nahdlatul Ulama as the largest da'wah organization in Indonesia in implementing da'wah strategies via Instagram accounts. This research was conducted on the official Nahdlatul Ulama Instagramaccount, @nuonline_id.This study aims to understand how the message format is presented in the @nuonline_id account and how the da'wah strategy is used by Nahdlatul Ulama on the @ nuonline_id account. Qualitative descriptive research was chosen to be the research method in this study. To make it easier for researchers to solve problems, the approach used is the content analysis approach. In this study, the results show that @ nuonline_id in terms of content form has 2 strategies, namely: first, in presenting images with insertions of words and selecting templates that show the characteristics of Nahdlatul Ulama. Second, presenting the video by providing interesting illustrations. Apart from that, in terms of the nature of the message, the strategy can also be seen in the content of the da'wah messages which are informative, persuasive and educational.
\end{abstract}

Keywords: Strategy, Multimedia Da'wah, Instagram, @nuonline_id

\title{
A. PENDAHULUAN
}

Dakwah, pada dasarnya disampaikan tidak hanya dalam bentuk ceramah, khutbah yang bersifat formal dengan berdiri diatas mimbar, seperti yang sebagian besar masyarakat pahami. Melainkan, dakwah dapat berbentuk apapun bisa lisan, tulisan dan perbuatan, bisa langsung atau tidak langsung. Guna kelancaran kegiatan berdakwah, perlu adanya peran media di dalamnya. Media sendiri merupakan sarana yang dipergunakan oleh seseorang guna memudahkan penyampaian sebuah informasi. Adapun beberapa bentuk media dakwah tersebut antara lain: media cetak yang meliputi koran, buku, bulletin, dan majalah. Media elektronik yang meliputi telepon seluler, laptop dan komputer. Media audio yaitu media yang hanya memuat pesan auditif (suara) saja, seperti 
tape deck, radio. ${ }^{1}$ Media visual yaitu media yang hanya memuat suatu objek untuk dilihat, seperti gambar dan poster. Sedangkan media audio visual yaitu media yang memuat suatu objek yang dapat didengar dan dilihat, seperti televisi dan film dokumenter.

Dakwah dengan menggunakan program audio visual dapat disebut juga dengan dakwah multimedia. Multimedia sendiri merupakan kumpulan berbagai macam bentuk informasi baik berbentuk kata, gambar, video, musik, animasi dan lain sebagainya. ${ }^{2}$ Dengan adanya dakwah multimedia ini mempermudah kegiatan seorang dai dalam menyampaikan dakwahnya, karena memiliki jangkauan yang cukup luas. Selain itu, diera milenial saat ini memungkinkan mereka untuk lebih mudah mengakses materi dakwah. Ketika multimedia digunakan secara efektif dalam kegiatan berdakwah, dakwah dapat dilakukan dengan mudah.

Kemajuan teknologi saat ini, terlebih khususnya pada teknologi informasi telah menggeser pemikiran manusia yang ingin lebih cepat dalam menerima atau mengakses informasi. Internet menjadi salah satu bukti adanya kemajuan teknologi informasi ini. Internet telah memberikan manfaat besar kepada masyarakat. Internet juga menjadi solusi dalam komunikasi jarak jauh yang selama ini menjadi penghambat. Karena saat ini, jaringan internet sudah menjangkau luas diberbagai daerah. Seiring dengan adanya internet tersebut, muncullah media sosial ditengah-tengah keidupan masyarakat. Terdapat berbagai macam media sosial yang dapat diakses oleh para pengguna antara lain: whatsapp, instagram, facebook, line, twitter, pinterest, wechat, youtube, vimeo, linkedin, telegram, path, snapchat, mindtalk dan tik tok.

Instagram, kini menjadi media sosial yang dirasa cukup efektif dalam menyampaikan dakwah. Terlebih pada ruang lingkup generasi milenial, karena mereka lebih aktif pada penggunaan media sosial. Dengan adanya fitur-fitur menarik yang ditawarkan, menjadikan instagram banyak digemari dan diakses. Kata "instagram" sendiri

${ }^{1}$ Samsul Munir Amin, Ilmu Dakwah, Cetakan Kedua, (Jakarta: Amzah, 2013), hlm. 118

${ }^{2}$ Abd. Aziz Ahmad, Dakwah, Seni dan Teknologi Pembelajaran, Jurnal Dakwah Tabligh, Vol. 14, No. 1, Juni 2013, Hlm. 81 
tersusun dari dua suku kata yaitu "insta" yang diambil dari kata instant yaitu layaknya foto instan polaroid dengan berbentuk persegi dan kata "gram" yang diadopsi dari kata telegram yang artinya sebagai pengirim informasi dengan cepat dan mudah. ${ }^{3}$ Sedangkan secara istilah kata instagram dapat diartikan sebagai media yang digunakan untuk mengirim foto dan informasi dengan mudah dan cepat.

Instagram mulai diperkenalkan oleh Mike Krieger dan Kevin Systrom pada tahun 2010. Mereka berdua adalah lulusan Stanfrod University Amerika Serikat dengan jurusan yang tidak sama. Mike Krieger mengambil jurusan Symbolic Systems yang berkonsentrasi pada Human Computer Interaction. Sedangkan Kevin Systrom mengambil jurusan Management Science \& Engineering. Tidak membutuhkan waktu yang lama untuk menjaring masyarakat. Pada saat peluncuran pertama kali pada 6 Oktober yang hanya mengandalkan viral marketing sukses menarik sekitar 25 ribu pengguna. Kemudian dalam kurun waktu satu minggu, pengguna instagram betambah menjadi 100 ribu orang.

Terdapat penelitian terdahulu yang memiliki persamaan dan perbedaan terhadap penelitian penulis. Penelitian tersebut termuat dalam jurnal yang berjudul "Dakwah Melalui Media Sosial (Studi Tentang Pemanfaatan Media Instagram @cherbonfeminist Sebagai Media Dakwah Mengenai Kesetaraan Gender) oleh Aan Mohammad dkk, yang dimuat pada Jurnal Orasi Volume 10 No. 2. ${ }^{4}$ Persamaan dengan penelitian yang peneliti tulis adalah pada media sosial yang diteliti yaitu penggunaan instagram sebagai media dakwah. Sedangkan perbedaannya terdapat pada objek penelitian yaitu pada penelitian terdahulu objek penelitiannya adalah akun @ cherbonfeminist, sedangkan pada penelitian ini objeknya adalah akun @ nuonline_id. Selain itu, perbedaannya juga terletak pada pendekatan yang digunakan. Jika pada penelitian terdahulu menggunakan pendekatan studi kasus, maka pada penelitian ini peneliti menggunakan pendekatan content analysis.

${ }^{3}$ Bambang Dwi Atmoko, Instagram Handbook, (Jakarta: Media Kita, 2012), hlm. 8

${ }^{4}$ Aan Mohamad Burhanudin, dkk. Dakwah Melalui Media Sosial (Studi Tentang Pemanfaatan Media Instagram @cherbonfeminist Sebagai Media Dakwah Mengenai Kesetaraan Gender), Jurnal Orasi: Dakwah dan Komunikasi, Volume 10, No. 2 Desember 2019, Hlm. 241 
Meskipun instagram dibuat oleh orang non-muslim, akan tetapi media sosial tersebut mempunyai manfaat untuk siapapun apabila digunakan dengan baik. Salah satunya adalah digunakan sebagai media berdakwah termasuk Nahdlatul Ulama. Sebenarnya tidak hanya Nahdlatul Ulama saja yang memanfaatkan instagram tersebut, organisasi-organisasi islam lainnya pun juga ikut menggunakan aplikasi ini sebagai media dakwah. Seperti organisasi islam Lembaga Dakwah Islam Indonesia (LDII), Front Pembela Islam (FPI), Muhammadiyah, dan Hizbut Tahlil Indonesia (HTI).

Hanya saja Nahdlatul Ulama mempunyai cara pandang dakwah yang berbeda dengan organisasi-organisasi islam lainnya. Dalam hal ini, dakwah multimedia Nahdlatul Ulama salah satunya adalah melalui instagram dengan nama akun @nuonline_id. Kemudian nantinya dalam penelitian ini akan dipaparkan bagaimana format pesan dakwah yang disampaikan pada akun @nuonline_id dan bagaimana strategi yang digunakan Nahdlatul Ulama dalam mengembangkan dakwah melalui instagram @ nuonline_id.

\section{B. METODELOGI PENELITIAN}

Penelitian ini memakai metode penelitian deskriptif kualitatif. Di mana peneliti akan menggambarkan serta memaparkan (mendeskripsikan) fenomena yang tengah terjadi secara lebih mendalam. Sehingga nantinya dapat memudahkan pembaca dalam mendalami hasil dari penelitian ini. Dalam mempermudah mendapatkan data, peneliti menggunakan pendekatan content analysis (analisis isi). Analisis isi merupakan penelitian yang lebih mendalam terhadap isi suatu bentuk komunikasi yang menyeluruh baik berbentuk tulisan maupun gambar. Dimana dengan menggunakan pendekatan tersebut, peneliti akan mengetahui bagaimana strategi dakwah yang digunakan Nahdlatul Ulama melalui media sosial instagram @ nuonline_id. Terdapat beberapa skema penelitian dengan pendekatan content analisis ini antara lain: peng-unit-an, perekaman, penyederhanaan data, penarikan kesimpulan, dan penarasian data.

Akun@nuonline_id menjadi objek yang dipilih peneliti karena akun tersebut cukup aktif di media sosial. Hal tersebut dapat dilihat baik 
dalam hal memposting konten maupun interaksi yang ditunjukkan melalui pesan dan komentar. Hanya saja @nuonline_id hanya menanggapi komentar yang benar-benar penting atau berbobot saja. Selain itu, konten yang diposting pada akun @nuonline_id sangat bervariasi dan selalu menyuguhkan hal-hal baru (informasi up-date). Mulai dari konten yang berisi nasihat, motivasi, kajian keislaman dan lain sebagainya. Kelebihan dari instagram dibandingkan dengan media sosial lainnya adalah instagram memiliki banyak fitur seperti instastory, live ig, like, komentar, direct message, mention dan tidak ada batasan untuk postingan konten.

Adapun data yang diperoleh merupakan 2 sumber data yang meliputi sumber data primer dan sumber data sekunder. Sumber data primer adalah sumber data yang langsung didapatkan oleh peneliti melalui analisis pada akun instagram @ nuonline_id. Kemudian sumber data sekunder adalah sumber data yang didapatkan peneliti dengan menelusuri artikel, buku, jurnal serta internet yang berhubungan dengan permasalahan dalam penelitian yang sedang dilakukan. Penelitian ini dilakukan selama 3 bulan berturut-turut yakni mulai bulan AgustusOktober 2020.

\section{HASIL DAN PEMBAHASAN}

\section{Pengembangan Dakwah Melalui Media Sosial}

Penggunaan media dalam berdakwah sudah dikenal sejak zaman Nabi Muhammad saw. Selain berdakwah melalui lisan, Nabi Muhammad saw juga berdakwah melalui tulisan. Tulisan tersebut dituangkan kedalam surat-surat yang pada saat itu ditujukan untuk para raja-raja penguasa negeri. Surat-surat tersebut ditulis Nabi Muhammad saw. Dengan tujuan mengajak para raja non-muslim saat itu untuk masuk islam. ${ }^{5}$ Beliau menggunakan cara yang baik dan bijaksana guna memperlihatkan bahwa agama islam merupakan rahmat dan bentuk kasih sayang Allah swt. pada alam semesta.

Media dakwah mengalami perkembangan lagi pada masa wali songo. Hal tersebut dapat dilihat pada masa Sunan Bonang yang

${ }^{5}$ Bobby Rachman Santoso dkk, Surat Sebagai Media Dakwah: Studi Atas Praktek Dakwah Rasulullah Saw Terhadap Raja Heraclius, Kisra Abrawaiz, Muqouqis, dan Najasy, Jurnal Ilmu Dakwah, Vol. 35, No.1, 2015, Hlm. 199 
menggunakan musik sebagai media dakwah, yaitu dengan menciptakan alat musik gamelan yang disebut bonang. Selain itu, beliau juga berdakwah melalui tembang-tembang jawa seperti suluk dan tembang tamsil. Begitu juga dengan Sunan Kalijaga yang memanfaatkan wayang sebagai media dakwah. Pada saat itu, beliau berjasa dalam perkembangan wayang kulit dengan cerita yang bercorak islam yang berisi seperti prinsip ketauhidan, akhlak, muamalah dan ibadah. ${ }^{6}$ Awalnya wayang kulit tersebut bersumber pada cerita Ramayana dan Mahabarata, yang kemudian untuk kepentingan dakwah dimodifikasi oleh Sunan Kalijaga sehingga muncul lakon pewayangan seperti Jimat Kalimasada dan Dewa Ruci.

Seiring dengan perkembangan waktu, bentuk media dakwah mengalami kemajuan yang begitu pesat. Hadirnya media internet saat ini menjadi sebuah solusi terhadap efektifitas media dalam berdakwah. Karena, jangkauan media ini sangatlah luas serta dipastikan informasi-informasi yang tersedia pun beragam. ${ }^{7}$ Sehingga masyarakat pun dapat dengan mudah mengakses materi dakwah didalamnya. Adapun media sosial lainnya yang mempunyai keterikatan dengan media internet ini, yaitu media sosial. Diantara media sosial tersebut adalah instagram, facebook, twitter, whatsapp, telegram, youtube dan lain-lain.

Peluang terhadap tersampaikannya pesan dakwah kepada masyarakat saat ini cukup besar dengan adanya media sosial. Mengingat jumlah konsumsi masyarakat terhadap media sosial cukup tinggi. Sehingga diharapkan dengan pemanfaatan media sosial ini, pesan dakwah dapat tersampaikan secara lebih luas. Selain itu, bagi penerima pesan dakwah mereka bisa lebih banyak mengakses konten dakwah melalui media sosial tersebut sesuai dengan keinginan dan kebutuhan mereka. Karena, konten yang disediakan cukup beragam baik yang berupa gambar maupun video.

${ }^{6}$ Moh. Anif Arifani, Model Pengembangan Dakwah Berbasis Budaya Lokal: Analisis Tentang Akulturasi Islam dan Budaya Lokal Dakwah Sunan Kalijaga, Jurnal Ilmu Dakwah Vol. 4 No. 15 Januari-Juni 2010, hlm. 866

${ }^{7}$ Wahyu Ilaihi, Komunikasi Dakwah (Bandung, Remaja Rosdakarya, 2010), hlm.110 
Sejak tahun 2003, Nahdlatul Ulama memanfaatkan media sosial sebagai media dakwah secara daring (dalam jaringan) guna memperluas kegiatan dakwahnya atau bisa disebut sebagai dakwah multimedia. ${ }^{8}$ Adapun beberapa media sosial yang digunakan Nahdlatul Ulama, antara lain: Instagram dengan akun @ nuonline_id, facebook dengan akun NU Online, twitter dengan akun @nu_online, youtube dengan akun NU Online, website dengan akun www.nu.or.id. Redaksi NU Online sendiri berpusat di Gedung PBNU Lantai 5, Jalan Kramat Raya no 164, rt 7/ rw 2, Kenari, Senen, Jakarta Pusat. Akunakun pada media sosial tersebut merupakan akun resmi Nahdlatul Ulama' yang dibuat guna memberikan wadah informasi kepada masyarakat terkait kegiatan sosial, layanan keagamaan serta kebangsaan.

Seandainya media sosial tidak diikutcampurkan oleh organisasi-organisasi masyarakat islam dalam kegiatan dakwahnya, maka pesan-pesan tentang keburukan akan menyebar dengan mudah serta akan membutuhkan penanganan yang cukup rumit. Saat ini, perhatian terhadap media sosial yang hadir ditengah kehidupan masyarakat sangat penting dilakukan. Hal tersebut karena media sosial sudah begitu populer digunakan dari berbagai macam kalangan masyarakat. Munculnya kesadaran dari kalangan da'i dalam mengoptimalkan penggunaan media sosial sebagai media dakwah, dapat meminimalisir penyebaran ajaran yang menyimpang dan memperluas penyampaian pesan dakwah yang sesuai syariat islam.

\section{Instagram Sebagai Media Dakwah}

Media sosial instagram merupakan aplikasi jejaring sosial yang dapat digunakan untuk berbagi informasi, berbagi foto, dan video. ${ }^{9}$ Dengan ditawarkannya berbagai macam fitur di instagram, pengguna dapat mengakses informasi sekaligus dapat menunjukkan dan meningkatkan kreativitas mereka. Instagram sendiri resmi diluncurkan pertama kali pada tanggal 6 Oktober 2010 bakal

${ }^{8}$ Website resmi NU Online, https://www.nu.or.id/, diakses pada 12 November 2020 pukul 09.15

${ }_{9}^{9}$ Pengertian Instagram, https://id.m.wikipedia.org/wiki/instagram, diakses pada 22 Desember 2020, pukul 09.33 
perangkat IOS. Instagram sendiri dibuat dibawah perusahaan Burbn. Inc oleh Mike Krieger dan Kevin Systrom. Mereka adalah lulusan Stanford University, Amerika Serikat.

Hingga kini, media sosial instagram menjadi salah satu media yang banyak dimanfaatkan oleh masyarakat. Dalam bidang dakwah, dengan adanya fitur-fitur pendukung yang memungkinkan pelaku dakwah dapat membagikan materi dakwah mereka dengan berbagai macam bentuk. Sehingga sasaran dakwah akan tertarik dengan konten dakwah yang disampaikan. Fitur-fitur tersebut antara lain: home page, explore (pencarian), feed, profil, caption, mention, tagar, like, komentar, follow, name tage, direct message dan instagram story.

Konten dakwah yang disampaikan melalui media sosial instagram terdapat beberapa bentuk. Pertama, konten dapat berupa tulisan atau caption. Menariknya tidak ada batasan penggunaan jumlah kata pada caption yang ingin ditulis. Sehingga memberikan keleluasaan dai dalam menulis pesan dakwah yang ingin disampaikan. Kedua, konten dapat berupa gambar atau foto. Dai dapat mengunggah gambar maksimal 10 gambar dalam satu kali postingan, sedangkan jika menginginkan mengunggah banyak gambar dapat dengan melakukan beberapa kali postingan. Ketiga, konten dapat berupa video. Adapun ketentuan untuk video yang ingin diposting tersebut antara lain: durasi video maksimal 60 menit jika mempostingnya melalui web dan 15 menit jika mengunggahnya melalui perangkat seluler. Selain itu ketentuan rasio juga berbeda, pada video horizontal dengan rasio aspek 16:9 dan rasio aspek 9:16 untuk video vertikal.

Selain digunakan sebagai media hiburan, instagram juga memiliki beberapa manfaat lainnya antara lain:

a. Sebagai media dakwah, jangkauan instagram cukup luas jika dibandingkan media sosial lainnya. Sehingga penyajian pesan dakwah dapat lebih efektif dan efisien ${ }^{10}$

b. Meningkatkan kreativitas para pelaku dakwah dalam memberikan materi dakwahnya

${ }^{10}$ Guesty Tania, Skripsi: Analisis Isipesan Dakwah Ustadz Hanan Attaki Di Media Sosial Instagram, (Lampung:UIN Raden Pangeran, 2019), hlm. 53 
c. Bagi sasaran dakwah, mempermudah mereka dalam mengakses berbagai bentuk materi dakwah yang dapat disesuaikan kebutuhan dan keinginan setiap individu

d. Sebagai media promosi, para pelaku bisnis dapat memanfaatkan instagram untuk mempromosikan dan memasarkan produk mereka

e. Sebagai media komunikasi, instagram dapat mempermudah pengguna untuk melakukan komunikasi dengan keluarga atau kerabat yang tinggal berjauhan

\section{Format pesan dakwah Nahdlatul Ulama pada akun instagram @ nuonline_id}

Kata format menurut Kamus Besar Bahasa Indonesia artinya adalah bentuk, ukuran. ${ }^{11}$ Format disini dimaksudkan pada bentuk pesan dakwah yang disampaikan Nahdlatul Ulama melalui instagram @ nuonline_id. Akun@nuonline_id memiliki 778 ribu pengikut per Oktober 2020 dan sudah lebih dari 6 ribu konten yang diposting. Akun tersebut dikelola di bawah Redaksi NU Online yang berpusat di kantor PBNU (Pengurus Besar Nahdlatul Ulama) yang didalamnya terdapat tim khusus untuk pengelolaan dakwah di media sosial. Konten-konten yang disajikan pada @ nuonline_id ini tentu bersumber dari website resmi NU Online yaitu www.nu.or.id. Begitu juga dengan akun media sosial NU Online lainnya seperti youtube, facebook dan twitter.

Selain itu, komentar-komentar sebagai bentuk respon dari para pengikut@nuonline_id juga selalu diberikan, walau jumlahnya kadang tidak menentu. Dalam hal ini, @ nuonline_id terkadang hanya merespon komentar dari para pengikut yang berisi komentar atau tanggapan yang penting atau berbobot saja. Selebihnya, @ nuonline_id tidak memberikan respon atau balasan komentar. Ketika ada beberapa pengguna yang merasa tidak nyaman dengan postingan@nuonline_id kemudian memberikan opini yang keras dan tidak santun,maka@nuonline_id akan menanggapinya dengan tetap memberikan opini yang berisi kata-kata baik dengan maksud agar tidak menyinggung pihak siapapun.

${ }^{11}$ Ebta Setiawan, KBBI Online, https://kbbi.web.id/format.html, diakses pada 26 Oktober 2020 pukul 10.46 
Dalam analisis peneliti, dari bulan Agustus-Oktober 2020 menunjukkan bahwa konten yang diposting pada @nuonline_id sangat beraneka ragam. Adapun diantaranya 7 kategori konten tersebut disetiap bulannya adalah sebagai berikut:

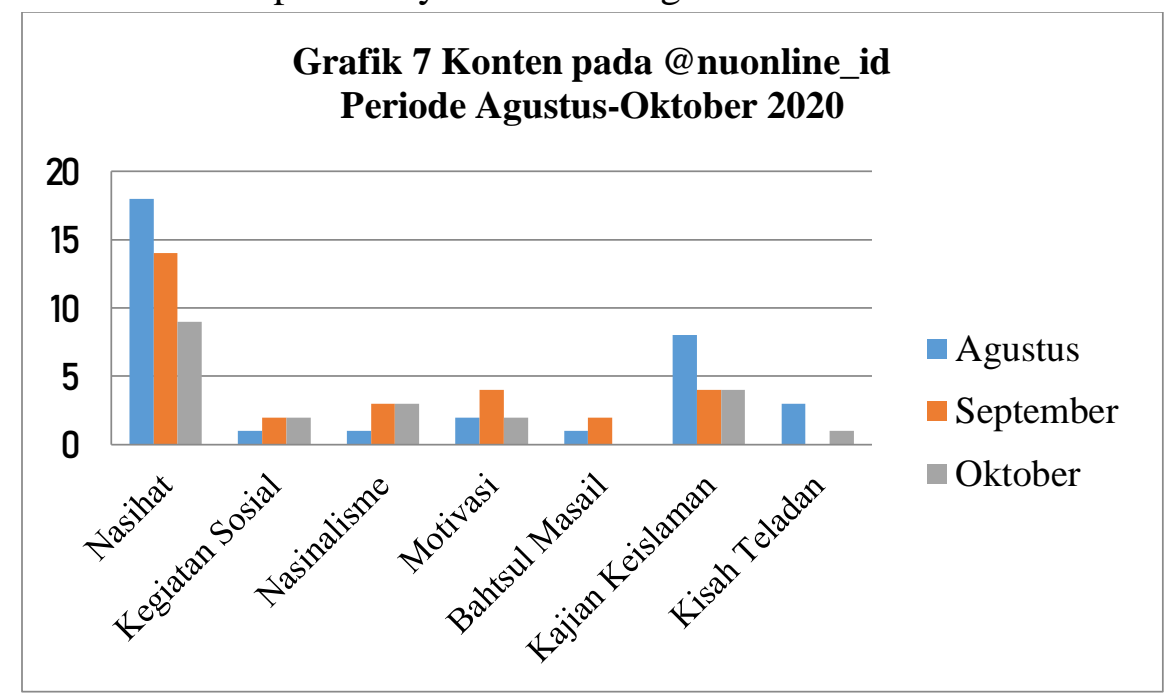

Sumber: $\underline{\text { https://instagram.com/nuonline_id }}$

Untuk pengunggahan 7 kategori konten tersebut memang tidak menentu atau sesuai jadwal, akan tetapi disetiap postingannya selalu ingin memberikan sisi positif. Ternyata instagram digunakan oleh Nahdlatul Ulama untuk membagikan pesan-pesan dakwah dalam berbagai macam bentuk konten antara lain:

a. Nasihat ${ }^{12}$

Konten terkait nasihat dapat dilihat pada postingan @nuonline_id 8 Agustus 2020 yang berisi, "Saat kamu merasa tidak ada orang yang berada dipihakmu, tenanglah masih ada Allah yang selalu ada bersamamu". Dijelaskan dalam tulisan tersebut bahwa sikap dan hati seseorang itu dapat berubah-ubah. Ketika suatu saat tidak ada orang yang mendukung kita, maka tidak perlu bersedih hati. Ingatlah bahwa Allah swt. akan senantiasa bersama

${ }^{12}$ Akun Instagram NU Online, https://instagram.com/nuonline id, diakses pada 30 Oktober 2020 pukul 22.13 
kita bagaimanapun keadaannya. Oleh sebab itu, selalu libatkan Allah swt. disetiap langkah dan usaha kita.

16 September 2020, @ nuonline_id kembali membagikan konten yang berisi "Tiadalah yang lebih ditakuti setan, para jin dan iblis melebihi hati yang berzikir. Ketika hati sedang ingat pada Allah, maka itulahyang paling ditakuti oleh setan". Hal tersebut dikutip dari nasihat Habib Mundzir bin Fuad Al-Musawa. Dijelaskan dalam tulisan tersebut bahwa kita dianjurkan untuk senantiasa berdzikir kepada Allah swt. Karena barang siapa yang hatinya senantiasa mengingat Allah swt, maka setan, jin dan iblis akan menjauh. Oleh karena itu, dimanapun dan kapanpun itu selalu ingatlah Allah swt dengan cara memperbanyak dzikir.

b. Kegiatan Sosial

Selain konten yang berisi tentang nasihat, @ nuonline_id juga mengunggah postingan terkait kegiatan sosial. Bukan dengan tujuan untuk pamer, akan tetapi diharapkan dengan adanya postingan tentang kegiatan sosial tersebut dapat meringankan beban orang lain dan supaya masyarakat dapat termotivasi. Seperti pada postingan @ nuonline_id pada 2 Agustus 2020 tentang kegiatan NU Care-LAZISNU yang kembali menyalurkan hewan qurban untuk masyarakat dhuafa di Bosnia dan Herzegovina. Melalui program Nusantara Berqurban-Solidaritas Tanpa Batas, pendistribusian hewan qurban tersebut dapat dilaksanakan ke seluruh wilayah nusantara dan negara lain.

Kemudian juga dapat dilihat pada postingan @nuonine_id pada 27 September 2020 tentang kegiatan sosial Majalah Aulia dan PWNU (Pengurus Wilayah Nahdlatul Ulama) Jawa Timur melalui LPBINU (Lembaga Penanggulangan Bencana dan Perubahan Iklim Nahdlatul Ulama) Jawa Timur yang bekerjasama dengan PT Sari Enesis Indah menyalurkan bantuan berupa perlengkapan kesehatan seperti Plossa, aromatherapy inhaler dan lotion anti nyamuk ke Ponpes Mamba'ul Ma'arif Denanyar Jombang. Perhatian tersebut muncul mengingat masih tingginya penyebaran covid-19 di daerah Jawa Timur. Terlebih salah satu tempat yang dipantau dan diperhatikan oleh pemerintah adalah pesantren, karena kemungkinan dapat menjadi klaster terbaru covid-19. 


\section{c. Nasionalisme}

Nahdlatul Ulama melalui akun instagram @ nuonline_id juga melaksanakan dakwah tentang sikap nasionalisme dengan membagikan konten-konten yang berisi terkait hal tersebut. Adapun seperti pada 6 Agustus 2020 terkait kegiatan khataman buku fiqih kebangsaan jilid 1 tentang merajut kebersamaan di tengah kebinnekaan bersama Ustaz Ahmad Muntaha AM (Founder Aswaja Muda \& Tim Penulis) yang dilaksanakan pada 7-10 Agustus. Dan khataman buku fiqih kebangsaan jilid 2 tentang menebar kerahmatan islam bersama Ustaz M. Mubasysyarum Bih (Mudir Ma'had Aly Lirboyo \& Tim Penulis) yang dilaksanakan pada 11-15 Agustus.

18 Agustus 2020 @nuonline_id membagikan ulang postingan dari salah satu pengguna instagram lain terkait postingan berupa foto sebagai ungkapan HUT RI yang ke-75, dengan tulisan "bangga menjadi santri indonesia". Dimana dengan adanya postingan tersebut, bisa menjadi pengaruh terhadap masyarakat agar ikut menunjukkan partisipasi mereka terhadap kecintaan pada negara.

d. Motivasi

Konten terkait motivasi ini disajikan guna memberikan semangat agar terus menebarkan benih kebaikan kepada sesama manusia. Seperti pada postingan @ nuonline_id pada 24 Agustus 2020 yang berisi motivasi dari Gus Nardirsyah Hosen, "Kita tidak tau Allah menurunkan rahmat-Nya lewat pintu yang mana. Meski satu pintu telah tertutup, teruslah mengetuk pintu-Nya dengan air mata doa dan penuh ikhtiar". Dari ungkapan tersebut dapat dilihat bahwa kita terus melakukan kebaikan, berikhtiar dan berdoa agar kita senantiasa semakin dekat dengan Allah swt. Karena tidak ada yang tahu tentang kehendak Allah, sehingga kita harus terus berikhtiar supaya mendapatkan rahmat-Nya.

Kata motivasi juga dapat dilihat pada postingan @ nuonline_id pada 14 Oktober 2020 yang berisi “Jangan pernah menyesali yang terlewat dan jangan bangga dengan apa yang kamu dapat karena itu adalah takdir" (Gus Baha'). Dari ungkapan diatas 
jelas bahwa kita tidak boleh menyesali sesuatu hal yang sudah terjadi. Karena hal itu hanya akan menjadi sia-sia, yang harusnya kita lakukan adalah mengikhlaskan dan mencoba memperbaiki agar kedepannya bisa menjadi lebih baik. Kemudian kita juga tidak boleh terlalu bangga dengan apa yang Allah kasih kepada kita, karena itu semua hanya titipan yang pada akhirnya akan kembali kepada-Nya. Sikap bersyukur itu harus dilakukan akan tetapi jangan sampai membuat kita terkesan pamer atau sombong.

e. Bahtsul masail

Bahtsul masail merupakan kegiatan rutin yang diadakan oleh Nahdlatul Ulama. Bahtsul masail sendiri merupakan kegiatan yang bertujuan untuk membahas suatu permasalahan yang terjadi di masyarakat. Melalui akun @nuonline_id, Nahdlatul Ulama membagikan hasil pembahasan dari setiap bahtsul masail yang dilakukan. Contohnya pada 9 Agustus 2020, @ nuonline_id membagikan hasil bahtsul masail terkait "bolehkah mengutamakan nafkah istri daripada ibu kandung?". Hasilnya dituliskan bahwa menurut Imam Nawawi, apabila ibunya masih berada dalam tanggung jawabnya kemudian nafkah ibunya tersebut sudah dipenuhi maka hukumnya diperbolehkan. Akan tetapi, ketika berada dalam dua pilihan maka boleh mengutamakan naskah istri dengan tetap menjaga perasaan ibunya.

Pada 01 September 2020, @nuonline_id kembali membagikan hasil bahtsul masail terkait "tes swab apakah membatalkan puasa ?". Hasilnya dituliskan bahwa sesuai dengan pengamatan terhadap keterangan empat mazhab, dihimbau kepada masyarakat yang ingin melakukan tes swab agar dilakukan ketika malam hari apabila sedang menjalankan ibadah puasa, baik puasa sunnah maupun qadha puasa. Hal tersebut dilakukan sebagai langkah antisipasi bila terjadi sesuatu yang tidak diinginkan nantinya.

f. Kajian keislaman

Kajian keislaman di sini merupakan kajian-kajian terkait ajaran islam yang dimaksudkan supaya dapat menambah pengetahuan seseorang tentang keagamaan. Ada banyak konten yang mengandung hal tersebut dalam akun @ nuonline_id, dua di 
antaranya yaitu: pertama, terkait "peristiwa- peristiwa penting di Bulan Safar" yang dibagikan pada 28 September 2020. Dijelaskan dalam postingan tersebut bahwa pada Bulan Safar terdapat peristiwa-peristiwa penting yang terjadi, antara lain: pernikahan Rasulullah saw. dengan khadijah, Rasulullah menikahkan Sayyidah Fatimah dengan Ali bin Abi Thalib, penaklukan khaibar pada tahun ke-7 $\mathrm{H}$, perang pertama dalam islam, yaitu perang abwa dan hijrahnya Rasulullah saw. dari Mekkah ke Madinah.

Kedua, terkait "hak seorang muslim atas muslim lainnya" yang dibagikan pada 16 Oktober 2020. Dijelaskan dalam postingan tersebut bahwa terdapat 6 hak seorang muslim atas muslim lainnya, meliputi: mengucapkan salam, menyampaikan nasihat, menghadiri suatu undangan, mendoakan ketika ada orang yang bersin, mengunjungi ketika ada yang sakit dan ketika ada orang meninggal dunia ikut serta mengantarkan jenazahnya.

g. Kisah teladan

Selain kajian keislaman, @nuonline_id juga menyajikan informasi tentang kisah teladan dari berbagai macam tokoh islam. Dengan harapan, pembaca dapat mengambil hikmah-hikmah dari kisah teladang tersebut. Contohnya, seperti postingan @ nuonline_id terkait "Kisah Ibnu Sina sembuhkan pangeran sakit jiwa dan minta disembelih" pada 10 September 2020. Singkatnya dalam cerita tersebut dijelaskan bahwa pada suatu ketika ibnu sina yang merupakan dokter terkenal berhasil mendiagnosis pemuda yang merupakan keponakan pejabat tinggi di Qabus. Hasilnya bahwa pemuda tersebut sakit bukan disebabkan oleh gangguan fisik akan tetapi disebabkan oleh gangguan kejiwaan yang disebut psikosomatis. Hal tersebut karena pemuda itu sedang mengalami jatuh cinta pada seorang gadis. Setelah hubungan mereka direstui akhirnya pemuda tersebut sembuh dari penyakitnya.

09 November 2020 kembali membagikan "kisah teladan Siti Khadijah binti Khuwailid" yang diceritakan oleh Umi Ratna UF. Dalam postingan tersebut mengulas sedikit terkait bagaimana sosok Siti Khadijah yang merupakan istri Rasulullah saw. selain beliau seorang saudagar kaya, beliau memiliki kecerdasan literasi 
dan logika keimanan yang dapat dilihat bagaimana respon beliau pada peristiwa turunnya wahyu yang pertama. Di mana Rasulullah saat itu merasa ketakutan kemudian Siti Khadijah mampu menenangkan hati Rasulullah saw. Secara psikologis, berita kenabian tersebut pun tidak langsung ditelan mentah-mentah, melainkan beliau berusaha berfikir dengan tenang, kritis dan logis. Secara akademis, Khadijah langsung mencari rujukan dan referensi ilmiahnya yaitu pada seorang ahli agama yaitu Waraqah bin Naufal.

Dengan adanya konten yang bermacam-macam terkait pesan dakwah tersebut, diharapkan mampu menarik minat masyarakat dan mengoptimalkan kegiatan amar ma'ruf nahi mungkar ini. Karena dengan mengkonsep konten yang disajikan secara berbedabeda, dilakukan guna memberikan kenyamanan kepada pembaca dan pengguna media sosial lainnya agar tidak bosan dengan postingan yang monoton.

\section{Strategi Nahdlatul Ulama dalam mengembangkan dakwah melalui instagram}

Strategi secara umum berarti suatu siasat yang digunakan seseorang atau suatu lembaga organisasi dalam mencapai tujuannya dengan memperhatikan peluang, sumber daya serta tantangan yang akan dihadapi. Strategi dalam berdakwah perlu adanya guna mempermudah penyampaian pesan-pesan dakwah kepada penerima pesan (mad'u) ${ }^{13}$ Penggunaan strategi yang baik dalam penyampaian pesan-pesan dakwah akan melalui sebuah perencanaan yang terencana secara matang supaya pesan dakwah dapat tersampaikan dengan baik. ${ }^{14}$ Terlebih penyampaian pesan dakwah melalui media sosial yang harus ada strategi-strategi agar mudah tersampaikan kepada masyarakat.

Instagram memiliki banyak fitur menarik yang ditawarkan bagi penggunanya. Dengan adanya fitur tersebut pengguna instagram akan

${ }^{13}$ M. Qadaruddin Abdullah dan Dinul Fitrah M, Strategi Dakwah dalam Merawat Pluralitas di Kalangan Remaja, Anida (Aktualisasi Nuansa Ilmu Dakwah) Vol. 19, No. 2, 2019, hlm. 181

${ }^{14}$ Imron Rosidi dan Rizal Zain, Strategi Radio Republik Indonesia (RRI) Pekanbaru dalam Menyampaikan Program Siaran Dakwah, Idarotuna, Vol. 1. No. 2, 2019, hlm. 6 
dimudahkan dalam berkreatifitas. Begitu pun dengan Nahdlatu Ulama' juga memanfaatkan beberapa fitur tersebut untuk mengembangkan dakwah islam diantaranya, fitur instagram stories, IG TV, caption, hashtag, mention, follow, like dan comment. Seperti halnya pengguna media sosial lainnya, NU memiliki strategi yang efektif untuk menarik minat masyarakat dan memberikan kemudahan masyarakat dalam memahami informasi yang disampaikan dalam setiap postingannya.

Dari sisi bentuk konten terdapat 2 strategi yang digunakan antara lain: Pertama, bukan hanya sekadar membagikan konten gambar saja, dalam akunnya @ nuonline_id juga memberikan sisipan kata atau teks sebagai penjelas gambar. Kemudian, pemilihan warna template gambar juga diperhatikan dengan memilih warna yang menunjukkan ciri khas dari Nahdlatul Ulama itu sendiri, yaitu warna hijau. Selain itu, warna putih juga dipilih sebagai warna kombinasi agar hasilnya nanti terlihat lebih menarik.

a. Seperti pada postingan @ nuonline_id 13 September 2020 terkait nasihat yang diberikan oleh KH Quraish Shihab. Adapun nasihat tersebut adalah "Semua dari kita sudah ditentukan umurnya oleh Allah. Tetapi tidak akan bisa diperpanjang usianya. Yang 60 ya 60 , yang 80 ya 80 dan seterusnya. Paling yang bisa adalah diberi keberkatan umurnya. Diberi keberkatan umur itu mengakibatkan walaupun anda tidak bisa memperpanjang usia, tetapi anda bisa memperlebarnya, memperdalamnya dan meninggikannya." Dalam postingan tersebut warna hijau digunakan sebagai background dengan kombinasi warna putih sebagai pelengkap. Selain itu penggunaan jenis font yang tegak lurus dapat mempermudah kita untuk membaca. Tak lupa penambahan foto tokoh juga ditambahkan, dalah hal ini KH Quraish Shihab.

b. Seperti pada postingan @ nuonline_id 18 September 2020 terkait kajian keislaman "langkah islam untuk hilangkan kesedihan". Dalam postingan tersebut seperti halnya poster, icon-icon tangan, tanda panah dan Al-Qur'an ditambahkan sebagai pelengkap tulisan. Watermark atau logo resmi NU Online juga ditambahkan dalam tulisan tersebut guna menunjukkan bahwa tulisan tersebut 
adalah benar dari NU Online. Masih dengan warna hijau dan putih yang digunakan sebagai warna dasar (background).

Kedua, selain gambar @ nuonline_id juga membagikan konten berbentuk video yang sudah dikonsep dengan sangat baik. Tidak sekadar video yang memperlihatkan seorang dai berceramah, melainkan video yang sudah dimodifikasi sedemikian rupa agar tidak terkesan biasa saja. Video tersebut diberikan ilustrasi-ilustrasi yang menarik, sehingga diharapkan masyarakat lebih mudah memahami isi dari video tersebut.

a. Seperti pada video yang dibagikan pada 14 Agustus 2020, di mana video tersebut disampaikan oleh KH Bahauddin Nur Salim terkait "Perilaku Sosial" yang tidak hanya dengan menampilkan beliau yang sedang berceramah, akan tetapi dibeberapa sisi video tersebut ditambahkan ilustrasi gambar orang lain yang disesuaikan dengan tema yang sedang dibahas. Hal tersebut bertujuan untuk melengkapi pesan yang disampaikan agar lebih mudah dipahami. Selain itu, juga ditambahkan terjemahan atau tulisan berjalan yang disesuaikan dengan setiap ucapan beliau.

b. Seperti pada postingan video 12 Agustus 2020 @nuonline_id, yang mana dalam video tersebutdisampaikan oleh Gus Ulil dengan topik "Hati Manusia". Dalam video itu penambahan ilustrasi potongan-potongan video diberikan secara keseluruhan. Dan tidak lupa terjemahan atau tulisan berjalan dibubuhkan agar lebih membantu orang lain dalam memahami pesan yang disampaikan.

Dari segi sifat pesan yang disampaikan secara umum, strategi yang digunakan Nahdlatul Ulama melalui instagram @nuonline_id yaitu melalui penyebarluasan pesan-pesan dakwah yang bersifat informatif, persuasif dan edukatif secara sistematik kepada sasaran dakwah guna memperoleh hasil yang maksimal. Adapun beberapa contoh dari sifat pesan-pesan dakwah tersebut antara lain:

a. Bersifat informatif, artinya pesan dakwah tersebut bertujuan untuk memberikan informasi pada masyarakat secara lebih luas dan guna menambah wawasan yang mereka miliki. Contohnya pada postingan @ nuonline_id 19 Agustus 2020 yang memberikan informasi terkait "Bacaan doa akhir tahun dan doa awal tahun". 
Dalam postingan tersebut dapat dijadikan sebagai media informasi terkait apa doa yang harus dibaca dalam menghadapi akhir tahun dan awal tahun.

b. Bersifat persuasif, artinya pesan dakwah tersebut bertujuan untuk mengubah suatu persepsi, sikap dan pendapat khalayak umum. Salah satu contohnya terdapat pada postingan @ nuonline_id 8 September 2020 terkait bahtsul masail tentang "Uang dari Aplikasi Game Online, Apakah Halal ?". dalam pembahsannya hukum asal dari akad muamalah pada dasarnya adalah boleh, dengan catatan tidak ada unsur-unsur yang diharamkan didalamnya. Terkait dengan permainan atau game online tersebut apabila tidak ada illat (alasan dasar) keharaman yang menjadikannya berubah menjadi alat malahi. Dengan adanya contoh pembahasan terkait bahtsul masail dapat mempengaruhi persepsi masyarakat. Dengan harapan mereka akan mendapatkan informasi yang benar, akurat terkait hukum sesuai dengan ajaran islam.

c. Bersifat edukatif, artinya pesan dakwah tersebut bertujuan untuk mendidik dan memberikan suatu pembelajaran. Salah satu contohnya terdapat pada postingan @ nuonline_id 21 Agustus 2020 terkait "Lomba Menulis Esai: dalam Rangka Harlah Gusdur" yang diadakan oleh Jaringan Gusdurian yang juga bekerja sama dengan @buonline_id. Hal tersebut dapat memberikan informasi yang bersifat edukatif dalam hal ini guna meningkatkan kemampuan-kemampuan para penulis terlebih penulisan esai.

\section{KESIMPULAN}

Berdasarkan content analysis (analisis isi), bentuk konten yang disajikan dalam akun@ @uonline_id ada berbagai macam, 7 bentuk diantaranya adalah: berupa nasihat, kegiatan sosial, nasionalisme, motivasi, bahtsul masail, kajian keislaman dan kisah teladan. Berbeda dengan organisasi islam lainnya, Nahdlatul Ulama memiliki strategi dalam dakwahnya melalui instagram @nuonline_id dari sisi bentuk konten yaitu dengan menunjukkan kreativitasnya dalam membuat 
konten dakwah baik berupa gambar seperti poster dan juga video. Selain itu, dari sisi sifat pesan yang disampaikan secara umum strategi tersebut dapat dilihat pada penyampaian pesan-pesan dakwah baik yang bersifat informatif, persuasif dan edukatif. Media sosial instagram di rasa efektif sebagai media komunikasi dan informasi, terlebih dalam bidang dakwah.

\section{DAFTAR PUSTAKA}

Abdullah, M. Qadaruddin dan Dinul Fitrah M. (Desember 2019). Strategi Dakwah dalam Merawat Pluralitas di Kalangan Remaja. Anida (Aktualisasi Nuansa Ilmu Dakwah). Vol. 19, No. 2. Tersedia: https://journal.uinsgd.ac.id/index.php/anida/article/view/7589.

Ahmad, Abd. Aziz. (Juni 2013). Dakwah, Seni dan Teknologi Pembelajaran, Jurnal Dakwah Tabligh, Vol. 14, No. 1. Tersedia: https://journal.uinalauddin.ac.id/index.php/tabligh/article/view/315

Akun Instagram NU Online, https://instagram.com/nuonline_id, diakses pada 30 Oktober 2020 pukul 22.13

Amin, Samsul Munir, "Media Dakwah," dalam Ilmu Dakwah, Cetakan Kedua, Jakarta: Amzah, 2013, hlm. 118

Arifani, Moh. Anif. (Januari-Juni 2010). Model Pengembangan Dakwah Berbasis Budaya Lokal: Analisis Tentang Akulturasi Islam dan Budaya Lokal Dakwah Sunan Kalijaga, Jurnal Ilmu Dakwah Vol. 4 No. 15. Tersedia:

https://journal.uinsgd.ac.id/index.php/idajhs/article/view/425

Atmoko, Bambang Dwi. Instagram Handbook. Jakarta: Media Kita. 2012. hlm. 8

Burhanudin Aan Mohamad, dkk. (Desember 2019). Dakwah Melalui Media

Sosial (Studi Tentang Pemanfaatan Media Instagram @cherbonfeminist Sebagai Media Dakwah Mengenai Kesetaraan Gender), Jurnal Orasi: Dakwah dan Komunikasi, Volume 10, No. 2. Tersedia:

https://syekhnurjati.ac.id/jurnal/index.php/orasi/artoicle/view/5658

Deva, Ado. https://resellerindo.com/fitur-instagram-terbaru/. diakses pada 22

Desember 2020 pukul 10:38

Ilaihi, Wahyu. Komunikasi Dakwah. Bandung: Remaja Rosdakarya. 2010. hlm. 110 
Pengertian Instagram. https://id.m.wikipedia.org/wiki/instagram. diakses pada 22 Desember 2020. pukul 09.33

Ramdhan, T. W. (2018). Islam Nusantara: Pribumisasi Islam ala NU. AlInsyiroh: Jurnal Studi Keislaman, 2(1), 73-91.

Ramdhan, T. W. (2019). Desain Kurikulum pendidikan Islam berbasis tauhid. Al-Insyiroh: Jurnal Studi Keislaman, 5(1), 118-134.

Rosidi, Imron dan Rizal Zain. (April 2019). Strategi Radio Republik Indonesia (RRI) Pekanbaru dalam Menyampaikan Program Siaran Dakwah. Idarotuna. Vol. 1. No. 2. Tersedia: https://ejournal.uinsuska.ac.id/index.php/idarotuna/article/view/7022.

Santoso, Bobby Rachman dkk. (Januari-Juni 2015). Surat Sebagai Media Dakwah: Studi Atas Praktek Dakwah Rasulullah Saw Terhadap Raja Heraclius, Kisra Abrawaiz, Muqouqis, dan Najasy. Jurnal Ilmu Dakwah. [online]. Vol. 35, No.1. Tersedia: https://journal.walisongo.ac.id/index.php/dakwah/article/view/1255.

Saputra, Wahidin. Pengantar Ilmu Dakwah. Jakarta: PT. Raja Grafindo Persada 2011, hlm. 2

Setiawan, Ebta. KBBI Online. https://kbbi.web.id/format.html. diakses pada 26 Oktober 2020 pukul 10.46

Tania, Guesty. "Analisis Isi Pesan Dakwah Ustadz Hanan Attaki di Media Sosial Instagram”. Skripsi, Jurusan Komuniaksi dan Penyiaran Islam. UIN Raden Pangeran, Lampung, 2019.

Website resmi NU Online. https://www.nu.or.id/. diakses pada 12 November 2020 pukul 09.15 